\title{
Effects of estrogen deficiency on sexual activity of climacteric women
}

\author{
Rodrigo Dias Nunes ${ }^{1,2 *}$, Camila Ractz' ${ }^{1}$ Jefferson Traebert ${ }^{1}$ \\ 'Universidade do Sul de Santa Catarina (UNISUL), Postgraduate Program in Health Sciences, Palhoça, SC, Brazil \\ 2Universidade do Sul de Santa Catarina (UNISUL), School of Medicine, Palhoça, SC, Brazil
}

\section{Abstract}

Objective: To evaluate the effects of hypoestrogenism on women's sexuality during the climacteric. Methods: A cross-sectional study was carried out on 195 women attending an outpatient clinic between September 2014 and May 2015. The Female Sexual Quotient (QS-F) questionnaire was administered and the chi-square test was used to test for homogeneity of proportions. The level of significance was $p<0.05$. Poisson regression was used for variables with $p<0.25$ to test for possible confounding variables. Results: The mean age of participants was 53.5 ( \pm 7.1) years. The final QS-F score ranged from 0-100, with an average of 56.0 ( \pm 23.8 ). Women aged 50 years and under were 1.12 times $(95 \% \mathrm{Cl} 1.01 ; 1.23)$ more likely to be associated with the "null to above moderate" category of sexual activity ( $p=0.025)$. Furthermore, those who had eight years of schooling or less were 0.88 times $(95 \% \mathrm{Cl} 0.79 ; 0.97)$ less likely to have poor sexual activity as compared to those who had a better education level ( $p=0.009)$. Conclusion: None of the symptoms of hypoestrogenism was associated with sexual activity. However, women under 50 years old and those with a higher level of education were more likely to be associated with poor sexual activity.

Keywords: sexuality; estrogen; climateric.

\section{Introduction}

Climateric phase refers to the physiological transition from the reproductive period to a non-reproductive period in women's life. It happens from around 40 to 60 years of age, when women's follicles deteriorate and they lose their reproductive capacity. ${ }^{1-4}$ The drop in estrogen production and progesterone after ovarian follicle depletion, as well as the reduction of plasma testosterone levels, lead to permanent interruption of the menstrual cycles and the emergence of symptoms characteristic of this stage. 5,6

Complaints related to vasomotor symptoms, such as hot flushes and intense sweating, are common. Cognitive impairment, mood swings, and depression are also observed in climacteric women, but it is unknown whether their origin is related to hormonal deficiency or psychosocial factors, such as aging. ${ }^{7}$

In the emotional sphere, estrogen modulates chemical neurotransmitters, and its absence interferes with mood characteristics. Hypoestrogenism reduces the secretion of brain endorphins, favoring depression, cognitive impairment, and even dementia processes. Psychological changes, often faced by climacteric and menopausal women, are of fundamental importance when sexual desire and involvement in sexual activity are taken into account, as well as issues related to the female body, its physiological changes and its recognition and acceptance by these women. ${ }^{8}$

Symptoms resulting from urogenital atrophy, such as vaginal dryness, dyspareunia, and urinary urgency also affect sexual activity. These symptoms affect both sexual activity and quality of life of these women. $5,6,9$

Financial support: None.

Conflicts of interest: The authors declare no conflicts of interest.

Submitted: July 11, 2017.

Accepted: November 21, 2017.

Study carried out at University of Southern Santa Catarina (UNISUL), Palhoça, SC, Brazil.

Copyright Nunes et al. This is an Open Access article distributed under the terms of the Creative Commons Attribution License, which permits unrestricted use, distribution, and reproduction in any medium, provided the original work is properly cited. 
Hypoestrogenism makes the epithelium of the genital tract thinner and fragile. Inadequate lubrication can cause dyspareunia, characterized by pain during sexual intercourse, a fact that will impair sexual functioning. 10,11 Hypoestrogenism also promotes the reduction of cutaneous collagen and alterations in fat distribution, causing changes in the body configuration, which, in turn, will affect women's self-image, favoring a lower self-esteem and, indirectly, loss of sexual desire. ${ }^{12,13}$

The decline in hormonal levels associated with women's natural aging causes loss of interest for sex and, consequently, decreases sexual activity. Furthermore, emotional factors, related to quality of relationship are involved with decreased libido and sexual functioning in this climacteric phase. ${ }^{4}$

Female sexuality is still a taboo, surrounded by myths and prejudices. The climacteric period is stigmatized, and biopsychosocial needs are repressed by a large number of women. ${ }^{14}$ Sexuality is recognized as one of the pillars of quality of life, and its approach is increasingly more frequent. ${ }^{15}$ Sexuality is multidimensional, not only influenced by anatomical and physiological factors, but also by psychosocial and cultural factors, as well as interpersonal relationships and life experiences. ${ }^{16}$

Health-seeking competencies by health professionals is required to assist women in their sexual dimension, thus contributing to quality care. ${ }^{17}$

Because hypoestrogenism is the main hormonal factor of climacteric symptomatology, causing many changes women experience in their body, it can then be responsible, directly or indirectly, for the large number of sexual dysfunctions that occur in this period, having strong impact on women's quality of life. ${ }^{17,18}$

The aim of this study was to identify the impact of clinical characteristics and hypoestrogenism symptoms on the sexual activity pattern in climacteric women, since physical and emotional factors also have a causal influence. In this way, health professionals would have better information to guide their patients, and make them understand that certain changes in sexuality are quite normal at this stage of their lives.

\section{Methods}

This was a cross-sectional study on climacteric women attending the gynecology and obstetrics outpatient clinic at the University of Southern Santa Catarina (Unisul), located in the municipality of Palhoça, state of Santa Catarina, Brazil. The study covered the period from September 2014 to May 2015.

The sample size was calculated using the prevalence study formula, with the following parameters: population size of 300 , prevalence of $30 \%$ outcome rate, $95 \%$ confidence interval $(\mathrm{Cl})$, plus $20 \%$ for possible losses, resulting in a required sample of 187 patients. Participants were selected by convenience sampling, being selected those who attended gynecological consultations on the days of the data collection.

Patients who had clinical conditions to respond to the questionnaire and agreed to participate were included in the study. The participants answered to a self-administered questionnaire, which lasted approximately 20 minutes. Some precautions were taken during the questionnaire administration to secure privacy and full completion. When necessary, the participant was provided with a questionnaire reading, exempt from any interpretation, and the answers were promptly indicated by the respondent. This questionnaire was administered in a single meeting. Subsequently, the medical records of the participating patients were examined.

The Female Sexual Quotient (QS-F) ${ }^{19}$ questionnaire has 10 questions, each of which must be answered on a scale of $0-5$. The sum of the 10 responses, multiplied by two, will result in a total score ranging from 0 to 100 . The seventh question requires a different treatment, that is, the score of the given answer (0-5) must be subtracted from 5 to have the final score of that question. The highest scores indicate a better pattern of sexual activity/satisfaction, according to the following breakdown: good to excellent (82-100); above moderate to good (62-80); moderate to above moderate (42-60); poor to moderate (22-40); null to poor (0-20), null meaning no sexual activity.

Data related to sociodemographic variables, clinical characteristics, climacteric symptomatology and sexuality characteristics were extracted from the medical records. These were the independent variables of the study, whereas sexual activity was the dependent variable. The data were exported to the SPSS 18.0 software for analysis.

Qualitative variables were described by absolute and relative frequencies, whereas quantitative variables were described as means and standard deviations for subsequent bivariate analysis. The chi-square test $\left(\chi^{2}\right)$ was used to test for homogeneity of proportions. The level of significance was set at $p<0.05$, and the variables with $p<0.25$ were submitted to Poisson regression analysis.

The data collection began after approval by the Research Ethics Committee of Unisul, in agreement with the Declaration of Helsinki (CAAE 32543614.3.0000.5369). 


\section{Results}

A total of 195 women suffering from climacteric symptoms participated in the study. The mean age was $53.5( \pm 7.1)$ years, ranging from 40 to 72 years. As for the skin color, 20 non-white women declared themselves to be mulatto or black.

The reported symptoms of hypoestrogenism were divided into three categories: clinical, psychological, and urogynecological symptoms, according to their origin (Table 1).

The final score, determined by the administration of the FSQ questionaire, ranged from 0 to 100 , with an average of 56.0 ( \pm 23.8$)$. Regarding the sexual activity patterns, 16 women (8.2\%) were in the "null to poor" category; $40(20.5 \%)$ were in the "poor to moderate" category; 53 (27.2\%) were in the "moderate to above moderate" category; 51 26.2\%) were in the "above moderate to good" category; and 35 (17.9) were in the "good to excellent" category (Table 2).

Table 1. Clinical, psychological, and urogynecological symptoms of hypoestrogenism among climacteric women. Palhoça, Santa Catarina, Brazil, 2016 ( $n=195)$

\begin{tabular}{lcc}
\hline \multicolumn{1}{l}{ Hypoestrogenism symptoms } & $\mathbf{n}$ & $\%$ \\
Clinical symptoms & & \\
Hot flushes & 128 & 65.5 \\
Irritability & 78 & 40.0 \\
Insomnia & 57 & 29.2 \\
Fatigue & 7 & 3.6 \\
Psychological symptoms & & \\
Mood swings & 59 & 30.3 \\
Depressive symptoms & 74 & 37.9 \\
Cognitive impairment & 3 & 1.5 \\
Urogynecological symptoms & & \\
Vaginal dryness & 32 & 16.4 \\
Urinary incontinence & 18 & 9.2 \\
\hline
\end{tabular}

Table 2. Hypoestrogenism symptoms according to sexual activity patterns among climacteric women. Palhoça, Santa Catarina, Brazil, $2016(n=195)$

\begin{tabular}{|c|c|c|c|c|c|}
\hline \multirow[t]{2}{*}{$\begin{array}{l}\text { Hypoestrogenism } \\
\text { symptoms }\end{array}$} & $\begin{array}{l}\text { Good to } \\
\text { Excellent }\end{array}$ & $\begin{array}{l}\text { Above Moderate } \\
\text { to Good }\end{array}$ & $\begin{array}{c}\text { Moderate to } \\
\text { Above Moderate }\end{array}$ & $\begin{array}{l}\text { Poor to } \\
\text { Moderate }\end{array}$ & Null to Poor \\
\hline & n (\%) & $n(\%)$ & n (\%) & n (\%) & n (\%) \\
\hline Yes & 17 (13.3) & $33(25.8)$ & 39 (30.5) & 28 (21.9) & $11(8.6)$ \\
\hline No & $18(26.9)$ & $18(26.9)$ & $14(20.9)$ & 12 (17.9) & $5(7.5)$ \\
\hline \multicolumn{6}{|l|}{ Irritability } \\
\hline Yes & 13 (16.7) & $20(25.6)$ & $18(23.1)$ & $21(26.9)$ & $6(7.7)$ \\
\hline
\end{tabular}


Table 2. Continued...

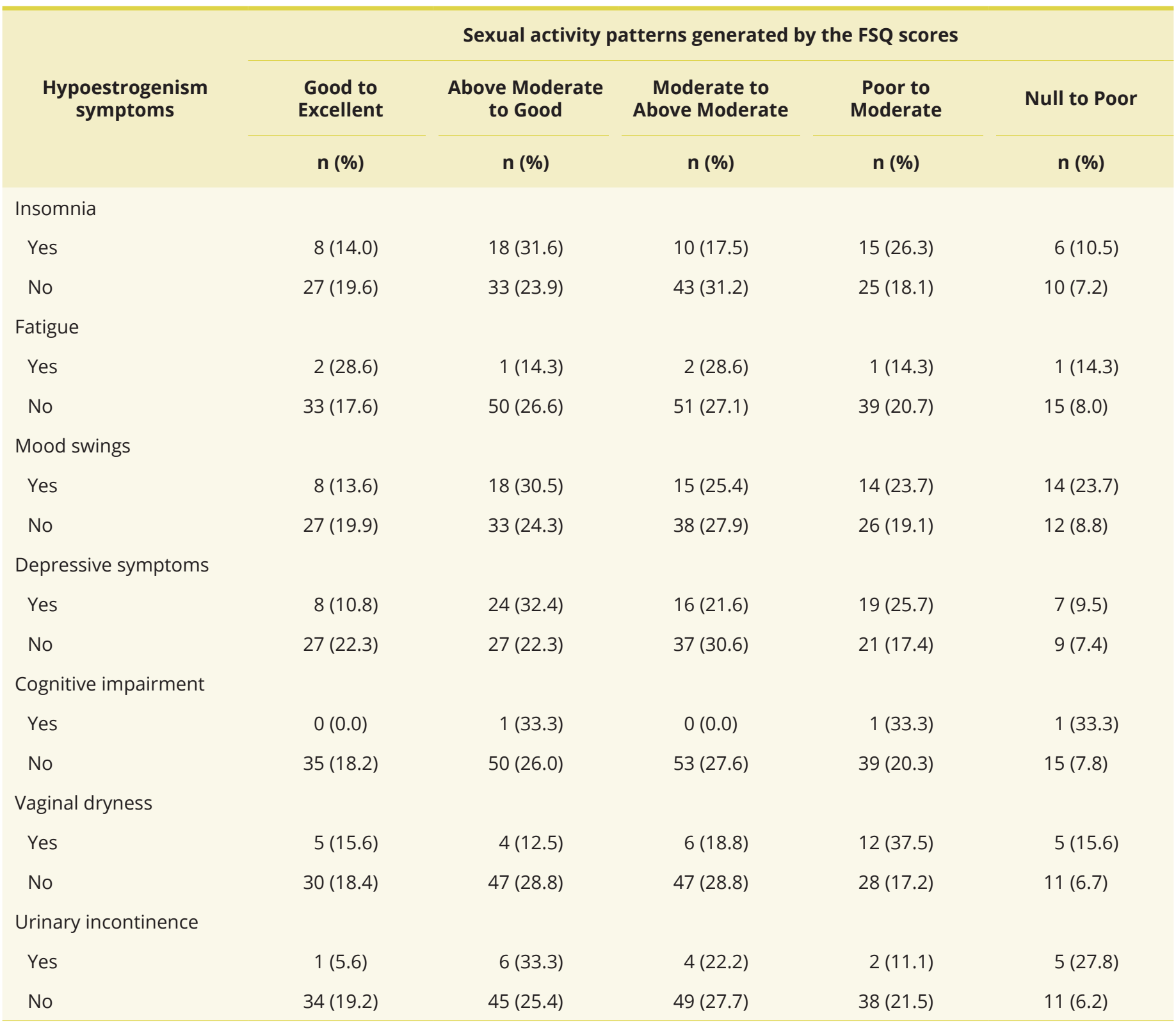

To carry out the analysis, the sexual activity categories resulting from the QS-F administration were regrouped, joining "good to excellent" and "above moderate to good" in one group, and "moderate to above moderate", "poor to moderate" and "null to poor" in another group.

The bivariate analysis showed a significant association between some sociodemographic variables and sexual activity (Table 3). However, none of the hypoestrogenism symptoms were significantly associated with sexual activity (Table 4).

However, hot flushes and vaginal dryness were part of the multivariate analysis model, along with age, presence of stable relationship, education, and body mass index. Poisson regression analysis showed hypoestrogenism symptoms did not interfere with sexual activity. However, women aged 50 years or younger were 1.12 times more likely to be associated with the "null to above moderate" category of sexual activity $(95 \% \mathrm{Cl} 1.01 ; 1.23)$ compared to those of older age $(p=0.025)$. Furthermore, the multivariate analysis showed that women who had eight years of schooling or less were 0.88 times less likely to be associated with poor sexual activity $(95 \% \mathrm{Cl} 0.79 ; 0.97)$ than better-educated women $(p=0.009)$ (Table 5). 
Table 3. Comparative analysis between sociodemographic characteristics and sexual activity patterns generated by the FSQ scores among climacteric women. Palhoça, Santa Catarina, Brazil, 2016 ( $n=195)$

\begin{tabular}{|c|c|c|c|c|}
\hline \multirow{3}{*}{$\begin{array}{l}\text { Sociodemographic } \\
\text { characteristics }\end{array}$} & \multicolumn{3}{|c|}{ Sexual activity patterns generated by the FSQ scores } & \multirow{3}{*}{$p$-values } \\
\hline & Null to Moderate & $\begin{array}{l}\text { Above Moderate to } \\
\text { Excellent }\end{array}$ & Total & \\
\hline & n (\%) & n (\%) & n (\%) & \\
\hline \multicolumn{5}{|l|}{ Age } \\
\hline$\leq 50$ years & $32(45.7)$ & $38(54.3)$ & 70 (35.9) & 0.022 \\
\hline$>50$ years & $78(62.4)$ & 47 (37.6) & $125(64.1)$ & \\
\hline \multicolumn{5}{|l|}{ Skin color } \\
\hline Whites & $101(57.7)$ & $74(42.3)$ & $175(89.7)$ & 0.263 \\
\hline Non-whites & $9(45.0)$ & $11(55.0)$ & $20(10.3)$ & \\
\hline \multicolumn{5}{|l|}{ Stable relationship } \\
\hline Yes & $86(60.6)$ & $56(39.4)$ & $142(72.8)$ & 0.050 \\
\hline No & $24(45.3)$ & $29(54.7)$ & $53(27.2)$ & \\
\hline \multicolumn{5}{|l|}{ Education } \\
\hline$\leq 8$ years & 85 (63.9) & $48(36.1)$ & $133(68.2)$ & 0.001 \\
\hline$>8$ years & $25(40.3)$ & 37 (59.7) & $62(31.8)$ & \\
\hline \multicolumn{5}{|l|}{ Body mass index } \\
\hline$<30 \mathrm{~kg} / \mathrm{m}^{2}$ & $68(50.4)$ & $67(49.6)$ & $135(69.2)$ & 0.009 \\
\hline$\geq 30 \mathrm{~kg} / \mathrm{m}^{2}$ & $42(70.0)$ & $18(30.0)$ & $60(30.8)$ & \\
\hline \multicolumn{5}{|l|}{ Climacteric onset } \\
\hline$\leq 50$ years & $71(54.2)$ & $60(45.8)$ & $131(67.2)$ & 0.372 \\
\hline$>50$ years & $39(60.9)$ & $25(39.1)$ & $64(32.8)$ & \\
\hline \multicolumn{5}{|l|}{ Menopause onset } \\
\hline$\leq 50$ years & $68(54.8)$ & $56(45.2)$ & $124(63.6)$ & 0.559 \\
\hline$>50$ years & $42(59.2)$ & $29(40.8)$ & $71(36.4)$ & \\
\hline
\end{tabular}

Table 4. Comparative analysis of clinical, psychological, and urogynecological symptoms of hypoestrogenism and sexual activity patterns generated by the FSQ scores among climacteric women. Palhoça, Santa Catarina, Brazil, 2016 ( $n=195)$

\begin{tabular}{|c|c|c|c|c|}
\hline \multirow[t]{2}{*}{$\begin{array}{l}\text { Hypoestrogenism } \\
\text { symptoms }\end{array}$} & Null to Moderate & $\begin{array}{c}\text { Above Moderate to } \\
\text { Excellent }\end{array}$ & Total & \multirow[t]{2}{*}{$p$-values } \\
\hline & n (\%) & n (\%) & n (\%) & \\
\hline \multicolumn{5}{|l|}{ Hot flushes } \\
\hline No & $32(47.8)$ & $35(52.2)$ & $67(34.4)$ & \\
\hline \multicolumn{5}{|l|}{ Irritability } \\
\hline Yes & 45 (57.7) & $33(42.3)$ & $78(40.0)$ & 0.768 \\
\hline No & $65(55.6)$ & $52(44.4)$ & $117(60.0)$ & \\
\hline
\end{tabular}


Table 4. Continued...

Sexual activity patterns generated by the FSQ scores

\begin{tabular}{|c|c|c|c|c|}
\hline \multirow[t]{2}{*}{$\begin{array}{l}\text { Hypoestrogenism } \\
\text { symptoms }\end{array}$} & Null to Moderate & $\begin{array}{l}\text { Above Moderate to } \\
\text { Excellent }\end{array}$ & Total & \multirow[t]{2}{*}{$p$-values } \\
\hline & n (\%) & n (\%) & n (\%) & \\
\hline \multicolumn{5}{|l|}{ Insomnia } \\
\hline No & $78(56.5)$ & $60(43.5)$ & $138(70.8)$ & \\
\hline \multicolumn{5}{|l|}{ Fatigue } \\
\hline Yes & 4 (57.1) & $3(42.9)$ & $7(3.6)$ & 0.968 \\
\hline No & $106(56.4)$ & $82(43.6)$ & $188(96.4)$ & \\
\hline \multicolumn{5}{|l|}{ Depressive symptoms } \\
\hline Yes & $42(56.8)$ & $32(43.2)$ & 74 (37.9) & 0.939 \\
\hline No & $68(56.2)$ & $53(43.8)$ & $121(62.1)$ & \\
\hline \multicolumn{5}{|l|}{ Cognitive impairment } \\
\hline Yes & 2 (66.7) & 1 (33.3) & $3(1.5)$ & 0.718 \\
\hline No & $108(56.3)$ & 84 (43.7) & $192(98.5)$ & \\
\hline \multicolumn{5}{|l|}{ Vaginal dryness } \\
\hline Yes & $23(71.9)$ & $9(28.1)$ & $32(16.4)$ & 0.046 \\
\hline
\end{tabular}

Table 5. Multivariate analysis between the sociodemographic characteristics and hypoestrogenism symptoms and sexual activity patterns generated by the FSQ scores among climacteric women. Palhoça, Santa Catarina, Brazil, 2016 ( $\mathrm{n}=195$ )

\begin{tabular}{|c|c|c|c|c|}
\hline \multirow{2}{*}{$\begin{array}{l}\text { Sociodemographic } \\
\text { and hypoestrogenism } \\
\text { characteristics }\end{array}$} & \multicolumn{4}{|c|}{ Null to moderate sexual activity patterns generated by the FSQ scores } \\
\hline & Crude $\mathrm{PR}(95 \% \mathrm{CI})$ & p-Values* & Adjusted $\operatorname{Pr}(95 \% \mathrm{CI})$ & $p$-Values** \\
\hline \multicolumn{5}{|l|}{ Age } \\
\hline$\leq 50$ years & $1.21(1.02-1.24)$ & 0.022 & $1.12(1.01-1.23)$ & 0.025 \\
\hline$>50$ years & 1.00 & & 1.00 & \\
\hline \multicolumn{5}{|l|}{ Stable relationship } \\
\hline Yes & $0.90(0.81-1.00)$ & 0.056 & $0.91(0.82-1.00)$ & 0.059 \\
\hline No & 1.00 & & & \\
\hline \multicolumn{5}{|l|}{ Education } \\
\hline$\leq 8$ years & $0.85(0.77-0.94)$ & 0.001 & $0.88(0.79-0.97)$ & 0.009 \\
\hline$>8$ years & 1.00 & & & \\
\hline
\end{tabular}

*Crude $p$-values; **Adjusted $p$-values by the other variables of the model. 
Table 5. Continued...

\begin{tabular}{|c|c|c|c|c|}
\hline \multirow{2}{*}{$\begin{array}{l}\text { Sociodemographic } \\
\text { and hypoestrogenism } \\
\text { characteristics }\end{array}$} & \multicolumn{4}{|c|}{ Null to moderate sexual activity patterns generated by the FSQ scores } \\
\hline & crude $\mathrm{PR}(95 \% \mathrm{CI})$ & p-Values* & ${ }_{\text {Adjusted }} \operatorname{Pr}(95 \% \mathrm{Cl})$ & $p$-Values** \\
\hline \multicolumn{5}{|l|}{ Body mass index } \\
\hline$<30 \mathrm{~kg} / \mathrm{m}^{2}$ & $1.51(1.04-1.28)$ & 0.009 & $1.09(0.98-1.21)$ & 0.104 \\
\hline$\geq 30 \mathrm{~kg} / \mathrm{m}^{2}$ & 1.00 & & & \\
\hline \multicolumn{5}{|l|}{ Hot flushes } \\
\hline Yes & $0.91(0.83-1.01)$ & 0.074 & $0.94(0.85-1.03)$ & 0.198 \\
\hline No & 1.00 & & & \\
\hline \multicolumn{5}{|l|}{ Vaginal dryness } \\
\hline Yes & $0.87(0.77-0.99)$ & 0.046 & $0.91(0.80-1.04)$ & 0.170 \\
\hline No & 1.00 & & & \\
\hline
\end{tabular}

\section{Discussion}

Assessment of hypoestrogenism symptoms was based on the participants' perceptions of their degree of satisfaction with their sexual activity.

Special care was taken regarding the methodology to ensure the validity of results. Quality of the data collection method was based on the administration of the QS-F, developed by Abdo, ${ }^{19}$ which is a validated tool for female sexuality surveys applied in Brazil, because of the reliability and validity of its parameters.

Respecting the participants' privacy and the time available for them to answer the questionnaire provided good quality of data collection. Such methodological care allowed avoiding research bias.

Given the scarce literature on the association between hypoestrogenism symptoms and sexual activity among climacteric women, this study presents the subject in an innovative way.

Analysis of the association between hot flushes and sexual activity patterns in the present study revealed that the "moderate to above moderate" category had the highest prevalence rate (30.5\%), while the "good to excellent" had the lowest prevalence (8.6\%). Cabral et al. ${ }^{20}$ and Alves et al. ${ }^{21}$ have found a similar sexual activity pattern in their studies, with an inversely proportional relationship between climacteric symptoms and sexual activity. Because of this similarity, the authors of those studies inferred that the presence of hot flushes interfered negatively with sexual activity of climacteric women. However, the present study did not find the same association.

Analysis of the association between irritability and sexual activity patterns revealed that the "poor to moderate" category had the highest prevalence (26.9\%), while the "null to poor" category had the lowest prevalence (7.7\%). A study by Alves et al. ${ }^{21}$ has demonstrated that the pattern of sexual activity may decline in patients with irritability. This fact is a common complaint in medical offices, and may be caused by estrogen deficiency, which generates emotional discomfort and impairs sexual activity with tranquility and pleasure. However, there may be confounding factors, since there was no such association in this sample.

Analysis of the association between insomnia and sexual activity patterns revealed that the "above moderate to good" category had the highest prevalence (31.6\%), while the "null to poor" category had the lowest prevalence $(10.5 \%)$. Silva et al. ${ }^{22}$ and Souza et al. ${ }^{23}$ have found that $86 \%$ of women had difficulty sleeping and $62.7 \%$ were satisfied with their sexual life, which means that insomnia was not a negative factor for poor sexual activity, given it occurred more frequently in women who were satisfied with their sexual life. The finding that insomnia does impair sexuality activity in climacteric women corroborates the results found in the current study.

Analysis of the association between fatigue and sexual activity patterns revealed that both "good to excellent" and "moderate to above moderate" categories had the highest prevalence (26.8\%). However, one cannot infer that fatigue has no influence on sexual activity just because different categories have shown the same prevalence percentage. Moreover, there are no reports in the literature to support the contrary.

Analysis of the association between mood swings and sexual activity patterns revealed a higher prevalence in the "above moderate to good" category and a lower prevalence in the "good to excellent" category. According to Oliveira et al., ${ }^{24}$ 
this psychological factor interferes with self-control and is responsible for behavioral changes that alter women's social relations. Based on this assertion, one can infer that mood swings may affect negatively women's sexual activity, which means that the more frequent the mood swings, the worse the impact on quality of life and, consequently, on woman's sexual activity. However, there were sociodemographic characteristics that affected this association.

Analysis of the association between depression and sexual activity patterns revealed that the "above moderate to good" category had the highest prevalence rate and the "null to poor" category had the lowest prevalence, which means the least depressed women were those with the lowest sexual activity pattern. In a study performed by Alves et al., ${ }^{21}$ who used the same pattern of sexual activity generated by the QS-F scores, have demonstrated that depression and other comorbidities may diminish sexual activity. Lucena et al. ${ }^{25}$ have reported that poor sexual activity may be a risk factor for depression, which leads to loss of self-esteem and self-confidence, and decreased libido. These divergent findings can be explained by the fact that depression will not always lead to poor sexual activity, as explained in this multivariate analysis.

Analysis of the association between cognitive impairment and sexual activity patterns revealed that the "above moderate to good", "poor to moderate", and "null to poor" categories had the highest prevalence rate (they all scored 33.3\%). According to De Lorenzi et al., ${ }^{26}$ hypoestrogenism reduces the secretion of brain endorphins, which favors cognitive impairment. Fernandes et al. ${ }^{27}$ have reported a divergent finding. According to their study, there is no consensus on what role, if any, low estrogen levels have on cognitive processes. Because of insufficient information on the relationship between hypoestrogenism and cognitive impairment, and based on the findings of this study, the association between these two characteristics could not be proved.

Analysis of the association between vaginal dryness and sexual activity patterns revealed that the "poor to moderate" category had the highest prevalence rate (37.5\%), and the "above moderate to good" category had the lowest prevalence rate $(12.5 \%)$. Silva et al. ${ }^{22}$ have found that the majority of the patients were satisfied with their sexual activity, and when they were asked about vaginal dryness, only $18.5 \%$ reported that symptom. These finding discrepancies can be explained by the different age bracket, since the participants in the present study were a little older than those of that study and, therefore, more exposed to hypoestrogenism, which causes vaginal dryness. Oliveira et al. ${ }^{24}$ have reported that vaginal lubrication happens more slowly in climacteric women than in younger women, and because of vaginal dryness, penetration can be painful and, consequently, affects women's sexuality. However, those findings were not replicated in the present study.

Analysis of the association between urinary incontinence and sexual activity patterns revealed that the "above moderate to good" category had the highest prevalence rate (33.3\%), and the "good to excellent" category had the lowest prevalence rate $(5.6 \%)$. This result can be explained by Ribeiro and Raimundo ${ }^{28}$ who found that women adjust to the situation over time and gain confidence to have pleasant sexual intercourses. Frigo et al. ${ }^{29}$ found that the "moderate to above moderate" category had the highest prevalence rate, while the "null to poor" category had the lowest. Once again, this climacteric symptom could not be proved in this study.

Transformations occurring during the climacteric period are caused by hypoestrogenism. The hormonal decline results in some clinical, psychological, and urogynecological manifestations that may affect sexuality. Nonetheless, psychological or behavioral conditions exert an increasing impact on the sexual activity of climacteric women, as shown in the findings discussed in this study. The association between hypoestrogenism and sexual activity patterns was shown to have no direct impact on sexuality. This finding is important to establish a broader behavioral approach for these patients.

The study concluded that the most prevalent pattern of sexual activity fell into the "moderate to above moderate" category, with $27.2 \%$ of the climacteric women in this group, but none of the hypoestrogenism symptoms studied were associated with sexual activity. Nonetheless, women up to 50 years of age were more likely to be associated with poor sexual activity than older women, while those with lower education were more likely to be associated with good sexual activity patterns than better-educated women.

\section{References}

1. Oliveira DM, Jesus MCP, Merighi MAB. Climatério e sexualidade: a compreensão dessa interface por mulheres assistidas em grupo. Texto Contexto Enferm. 2008;17(3):519-26. http://dx.doi.org/10.1590/S0104-07072008000300013.

2. Almeida AB. Sexualidade no climatério. In: Almeida AB, organizadora. Reavaliando o climatério: enfoque atual e multidisciplinar. Porto Alegre: Atheneu; 2003. p. 17-29.

3. Utian WH. The International Menopause Society menopause-related terminology definitions. Climateric. 1999;2(4):284-6. PMid:11915855. http://dx.doi.org/10.3109/13697139909038088.

4. De Lorenzi DRS, Saciloto B. Frequência da atividade sexual em mulheres menopausadas. Rev Assoc Med Bras. 2006;52(4):25660. PMid:16967145. http://dx.doi.org/10.1590/S0104-42302006000400027.

5. Bossemeyer R. Aspectos gerais do climatério. In: Fernandes CE, Melo NR, Wehba S, editores. Climatério Feminino: fisiopatologia, diagnóstico e tratamento. São Paulo: Lemos Editorial; 1999. p. 17-33. 
6. Aldrighi JM, Aldrighi CMS, Aldrighi APS. Alterações sistêmicas do climatério. Rev Bras Med. 2002;59:15-21. http://dx.doi.org/10.1590/ S0104-42302002000100019.

7. Dennerstein L, Lehert P, Guthrie J. The effects of the menopausal transition and biopsychosocial factors on well-being. Arch Women Ment Health. 2002;5(1):15-22. PMid:12503070. http://dx.doi.org/10.1007/s007370200018.

8. Fleury HJ, Abdo CHN. Modalidades de tratamento para sintomas sexuais na menopausa. Diagn Tratamento. 2010;15(4):187-90.

9. Speroff L, Glass RH, Kase NG. Clinical gynecologic endocrinology and infertility. 4th ed. Baltimore: Williams \& Wilkins. 1989. p. 134-55.

10. Fleury HJ. Sexualidade: menopausa e andropausa. Rev Bras Psicodrama. 2004;12(2):85-98.

11. Bulcão CB, Carange E, Carvalho HP, Ferreira-França JB, Kligerman- Antunes J, Backes J, et al. Aspectos fisiológicos, cognitivos e psicossociais da senescência sexual. Ciências Cognição. 2004;1:54-75.

12. Dennerstein L, Randolph J, Taffe J, Dudley E, Burger H. Hormones, mood, sexuality, and the menopausal transition. Fertil Steril. 2002;77(4, Suppl 4):42-8. PMid:12007901. http://dx.doi.org/10.1016/S0015-0282(02)03001-7.

13. Hartmann U, Philippsohn S, Heiser K, Ruffer-Hesse C. Low sexual desire in midlife and older women: personality factors, psychosocial development, present sexuality. Menopause. 2004;11(62):726-40. PMid:15543025. http://dx.doi.org/10.1097/01. GME.0000143705.42486.33.

14. Ramos D. Viva a menopausa naturalmente. São Paulo: Augustus; 1998.

15. Lopes GP. Sexualidade: fisiopatologia, diagnóstico e tratamento. In: Fernandes CE. Menopausa e tratamento. São Paulo: Editora Segmento; 2003. p. 117-24.

16. Favarato MECS, Aldrighi JM, Fráguas Jr R, Pires ALR, Lima SMRR. Sexualidade e climatério: influência de fatores biológicos, psicológicos e sócio-culturais. Reprod Clim. 2000;15(4):199-202.

17. Blümel JE, Chedraui P, Baron G, Belzares E, Bencosme A, Calle A, et al. A large multinational study of vasomotor symptom prevalence, duration, and impact on quality of life in middle-aged women. Menopause. 2011;18(7):778-85. PMid:21407137. http://dx.doi.org/10.1097/gme.0b013e318207851d.

18. Chedraui P, Pérez-López FR, Mezones-Holguin E, San Miguel G, Avila C. Assessing predictors of sexual function in mid-aged sexually active women. Maturitas. 2011;68(4):387-90. PMid:21237590. http://dx.doi.org/10.1016/j.maturitas.2010.12.004.

19. Abdo CHN. Elaboração e validação do quociente sexual - versão feminina, uma escala para avaliar a função sexual da mulher. RBM Rev Bras Med. 2006;63(9):477-82.

20. Cabral PUL, Canário ACG, Spyrides MHC, Uchôa SAC, Eleutério Jr J, Amaral RLG, et al. Influência dos sintomas climatéricos sobre a função sexual de mulheres de meia idade. Ver Bras Ginecol Obstet. 2012;34(7):329-34. http://dx.doi.org/10.1590/ S0100-72032012000700007.

21. Alves ERP, Costa AM, Bezerra SMMS, Nakano MAS, Cavalcanti AMTS, Dias MD. Climatério: a intensidade dos sintomas e o desempenho sexual. Texto Contexto Enferm. 2015;24(1):64-71. http://dx.doi.org/10.1590/0104-07072015000590014.

22. Silva AR, Ferreira TF, Tanaka ACA. História ginecológica e sintomatologia climatérica de mulheres pertencentes a uma unidade de saúde pública do estado do Acre. Rev Bras Cresc e Desenv Hum. 2010;20(3):778-86.

23. Souza CL, Aldrighi JM, Lorenzi Fo G. Qualidade do sono em mulheres paulistanas no climatério. Rev Assoc Med Bras. 2005;51(3):170-6. PMid:16007304. http://dx.doi.org/10.1590/S0104-42302005000300019.

24. Oliveira DM, Jesus MCP, Merighi MAB. O climatério sob a ótica de mulheres assistidas em uma unidade de saúde da família de Juiz de Fora-Minas Gerais. Rev APS. 2008;11(1):42-53.

25. Lucena BB, Abdo CHN. Considerações sobre a disfunção sexual feminina e a depressão. Diagn Tratamento. 2012;17(2):82-5.

26. De Lorenzi DRS, Baracat EC, Saciloto B, Padilha Jr I. Fatores associados à qualidade de vida após menopausa. Rev Assoc Med Bras. 2006;52(5):312-7. PMid:17160304. http://dx.doi.org/10.1590/S0104-42302006000500017.

27. Fernandes RCL, Silva KS, Bonan C, Zahar SE, Marinheiro LP. Avaliação da cognição em mulheres no climatério. Cad Saude Publica. 2009;25(9):1883-93. PMid:19750376. http://dx.doi.org/10.1590/S0102-311X2009000900003.

28. Ribeiro JP, Raimundo A. Satisfação sexual e percepção de saúde em mulheres com incontinência urinária. Anal Psicol. 2005;3(23):305-14.

29. Frigo LF, Bitencourt TF, Pivetta HMF. A influência da incontinência urinária na satisfação sexual e na qualidade de vida em mulheres climatéricas. Rev Epidemiol Control Infect. 2014;4(4):233-7.

\author{
*Correspondence \\ Rodrigo Dias Nunes \\ Universidade do Sul de Santa Catarina (UNISUL) \\ Av. Pedra Branca 25, Cidade Universitária \\ CEP 88137-270, Palhoça, SC, Brazil \\ Tel.: +55 (48) 99932-9727 \\ E-mail: rodrigo.dias.nunes@hotmail.com
}




\section{Authors information}

RDN - Msc, M.D. - Assistant Coordinator of Medicine School; University of Southern of Santa Catarina. CR - M.D. - University of Southern of Santa Catarina. JT - PhD - Coordinator of Postgraduate Program in Health Sciences; University of Southern of Santa Catarina.

\section{Authors contribution}

RDN: Conception, analysis and interpretation of the data, reviewing and criticizing the intellectual content, agreeing with the final version of the article. CR: Conception, analysis and interpretation of the data, reviewing and criticizing the intellectual content, agreeing with the final version of the article. JT: Conception, analysis and interpretation of the data, reviewing and criticizing the intellectual content, agreeing with the final version of the article. 